\title{
Sources and light absorption of water-soluble organic carbon aerosols in the outflow from northern China
}

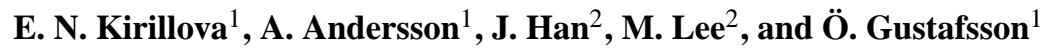 \\ ${ }^{1}$ Department of Applied Environmental Science (ITM) and the Bolin Centre for Climate Research, Stockholm University, \\ 10691 Stockholm, Sweden \\ ${ }^{2}$ Department of Earth and Environmental Sciences, Korea University, 136-701 Seoul, South Korea
}

Correspondence to: Ö. Gustafsson (orjan.gustafsson@itm.su.se)

Received: 9 July 2013 - Published in Atmos. Chem. Phys. Discuss.: 25 July 2013

Revised: 11 December 2013 - Accepted: 5 January 2014 - Published: 7 February 2014

\begin{abstract}
High loadings of anthropogenic carbonaceous aerosols in Chinese air influence the air quality for over one billion people and impact the regional climate. A large fraction $(17-80 \%)$ of this aerosol carbon is water-soluble, promoting cloud formation and thus climate cooling. Recent findings, however, suggest that water-soluble carbonaceous aerosols also absorb sunlight, bringing additional direct and indirect climate warming effects, yet the extent and nature of light absorption by this water-soluble "brown carbon" and its relation to sources is poorly understood. Here, we combine source estimates constrained by dual carbon isotopes with light-absorption measurements of watersoluble organic carbon (WSOC) for a March 2011 campaign at the Korea Climate Observatory at Gosan (KCOG), a receptor station in SE Yellow Sea for the outflow from northern China. The mass absorption cross section at $365 \mathrm{~nm}$ $\left(\mathrm{MAC}_{365}\right)$ of WSOC for air masses from N. China were in general higher $\left(0.8-1.1 \mathrm{~m}^{2} \mathrm{~g}^{-1}\right)$, than from other source regions $\left(0.3-0.8 \mathrm{~m}^{2} \mathrm{~g}^{-1}\right)$. However, this effect corresponds to only $2-10 \%$ of the radiative forcing caused by light absorption by elemental carbon. Radiocarbon constraints show that the WSOC in Chinese outflow had significantly higher fraction fossil sources (30-50\%) compared to previous findings in S. Asia, N. America and Europe. Stable carbon $\left(\delta^{13} \mathrm{C}\right)$ measurements were consistent with aging during long-range air mass transport for this large fraction of carbonaceous aerosols.
\end{abstract}

\section{Introduction}

High emissions of anthropogenic carbon aerosols from highly industrialized and populated northern and eastern China (Fig. 1) greatly influence the regional climate and air quality of the whole East Asian region. The water-soluble organic carbon (WSOC) is a substantial component of East Asian aerosols with concentrations spanning from 17 to $80 \%$ of the total organic carbon (TOC) (Feng et al., 2006, 2007; Duvall et al., 2008; Pathak et al., 2011; Huang et al., 2012). WSOC may influence regional climate through several mechanisms. WSOC affects the particle's hygroscopicity and hence the ability of aerosol particles to act as cloud condensation nuclei $(\mathrm{CCN})$ thus contributing to the indirect aerosol climate effects (e.g., Charlson et al., 2001; Svenningsson et al., 2006; Asa-Awuku et al., 2008). It has recently been found that WSOC exhibits light-absorbing ("brown carbon" BrC) properties (Cheng et al., 2011, Zhang et al., 2011). This water-soluble $\mathrm{BrC}$ thus potentially contributes both a direct climate forcing (Chung et al., 2012; Bahadur et al., 2012; Jacobson, 2012) and a semi-direct climate effect through heating and evaporation of clouds (Jacobson, 2012).

There is a need to better understand the sources, properties and atmospheric processing of WSOC. It has been suggested that WSOC in atmospheric particles may come from a wide range of primary and secondary sources (e.g., Decesari et al., 2007; de Gouw et al., 2008). A few initial studies with direct measurement of the natural abundance radiocarbon content of WSOC appears promising to constrain the sources of this large aerosol carbon fraction. Short-term radiocarbon-based studies of WSOC in North America and Europe suggest 


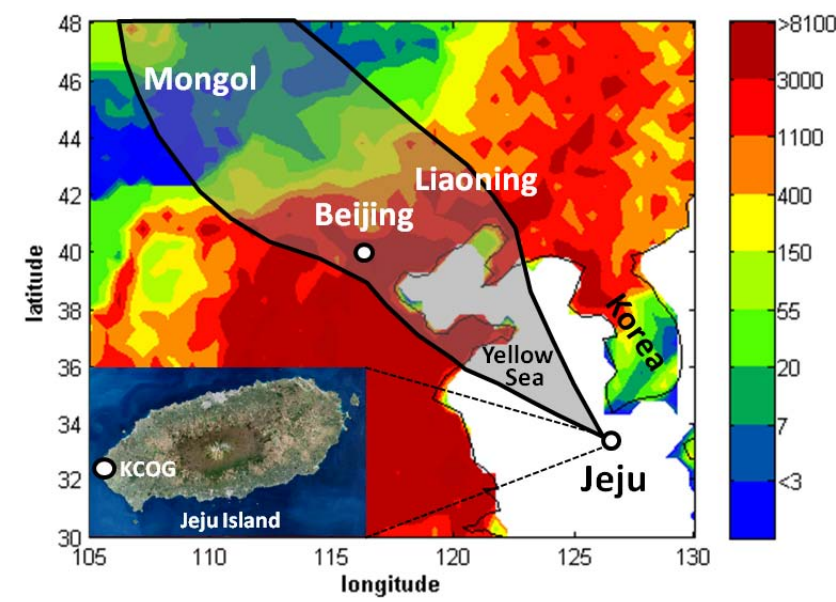

Fig. 1. Map depicting bottom-up emission inventory estimates of anthropogenic total organic carbon (TOC) estimated as the sum of black carbon (BC) and organic carbon (OC) in tons $\mathrm{yr}^{-1}$ per $0.5^{\circ} \times 0.5^{\circ}$ grid in year 2006 (Zhang et al., 2009). The five main geographical source regions from back trajectories (BTs) analysis for the present March 2011 campaign (GoPoEx - Gosan Pollution Experiment) are indicated: Beijing, Liaoning, Mongol, Yellow Sea and Korea. The shaded sector between the black lines show the predominant range of BTs of the Chinese outflow for the study period. The location of the Korean Climate Observatory at Gosan (KCOG) on Jeju Island is shown in the inset satellite image, provided by NASA (http://earthobservatory.nasa.gov/IOTD/view.php?id=35900).

an overwhelming contribution of modern carbon sources to WSOC in both rural and urban environments (Szidat et al., 2004; Weber et al., 2007; Wozniak et al., 2008, 2012a, b; Kirillova et al., 2010). Recent year-round ${ }^{14} \mathrm{C}-\mathrm{WSOC}$ campaigns at two regional background sites constrained a $20 \%$ fossil contribution in South Asia (Kirillova et al., 2013). A larger contribution of fossil fuel combustion to elemental carbon (EC) was found in East Asia compared to South Asia (Zhang et al., 2009; Ramana et al., 2010; Chen et al., 2013). To test the postulation that biomass burning is the predominantly largest source of WSOC and water-soluble BrC (e.g., Hoffer et al., 2006; Asa-Awuku et al., 2008), a radiocarbonbased investigation of WSOC sources over the East Asia was performed.

Furthermore, the stable carbon isotope signal $\left(\delta^{13} \mathrm{C}\right)$ can be used to differentiate not only the sources but also the atmospheric processing of the carbonaceous aerosols as it additionally reflects kinetic isotope effects (KIE) induced by transformation reactions during both primary aerosol and precursor emissions as well as during atmospheric transport (Anderson et al., 2004; Widory, 2006; Aggarwal and Kawamura, 2008; Das et al., 2010; Iannone et al., 2010; Kirillova et al., 2013).

In this paper we present carbon isotope-constrained source apportionment and light-absorbing properties of WSOC from the Gosan Pollution Experiment (GoPoEx), performed at the Korea Climate Observatory at Gosan (KCOG), Jeju Island, SE Yellow Sea, in March 2011. The findings quantify the light absorption effect and establish that, contrary to other regions, fossil sources are important for WSOC in the Chinese outflow.

\section{Materials and methods}

\subsection{Sampling site and sampling program}

The Gosan Pollution Experiment (GoPoEx) was conducted at the Korea Climate Observatory at Gosan (KCOG, $72 \mathrm{~m}$ a.s.1, 33.17 $\mathrm{N}, 126.10^{\circ} \mathrm{E}$ ) during 8-27 March 2011. $\mathrm{KCOG}$ is located in a rural area at the western tip of Jeju Island, $100 \mathrm{~km}$ south of the Korean peninsula (Fig. 1), and is a part of The Aerosol Characterization Experiments (ACE) Asia (Huebert et al., 2003), Advanced Global Atmospheric Gases Experiment (AGAGE, http://agage.eas.gatech. edu/), Global Atmosphere Watch (GAW) program (www. wmo.int/pages/prog/arep/gaw/gaw_home_en.html), and the International Atmospheric Brown Cloud (ABC) project (www.rrcap.unep.org/abc/). During GoPoEx, measurements of gaseous components (e.g., $\mathrm{CO}$ and $\mathrm{SO}_{2}$ ) and bulk particulate parameters (e.g., $\mathrm{PM}_{2.5}, \mathrm{PM}_{10}$, elemental carbon (EC)) as well as meteorology descriptors were collected at high frequency (averaged to $\leq 1 \mathrm{~h}$, Fig. 2). These measurements, in conjunction with HYSPLIT forecast back trajectories (BTs) and weather maps from the Korean Meteorological Association (KMA) were used to guide the high-volume filter sampling, with the aim of obtaining geographical sourceregion specific filter collections. Aerosols were collected on pre-combusted quartz-fiber filters using high volume $\mathrm{PM}_{2.5}$ (model DH77, Digitel A.G., Switzerland) and TSP samplers. The filter samples (1-26) collected during the campaign (Fig. 2, Supplement Table S1) were analyzed for concentrations of WSOC and total organic carbon (TOC), their isotope compositions and optical properties of the carbonaceous aerosols.

\subsection{Analysis of carbonaceous aerosol fractions}

The aerosol total organic carbon (TOC) concentrations were measured with a thermal-optical transmission (TOT) analyzer (Sunset Laboratory, Tigard, OR, USA) using the standard NIOSH 5040 method (Birch and Cary, 1996) but with the difference that the samples were acidified prior to analysis (by fumigation in open glass Petri dishes held in a desiccator over $12 \mathrm{M}$ hydrochloric acid for $24 \mathrm{~h}$ and subsequently dried at $60^{\circ} \mathrm{C}$ for $1 \mathrm{~h}$ ) to remove the carbonates. TOC thus represents all organic carbon in the chemical sense of the word (inorganic carbon is equal to carbonates), thus also including elemental carbon (EC). TOC concentration values were blank corrected and the field blank input was on average $10 \%\left(1.19 \pm 0.34 \mathrm{SD}, \mu \mathrm{g} \mathrm{cm}^{-2} ; n=4\right)$ for TSP and $11 \%\left(0.74 \pm 0.08 \mathrm{SD}, \mu \mathrm{g} \mathrm{cm}^{-2} ; n=4\right)$ for $\mathrm{PM}_{2.5}$. The 


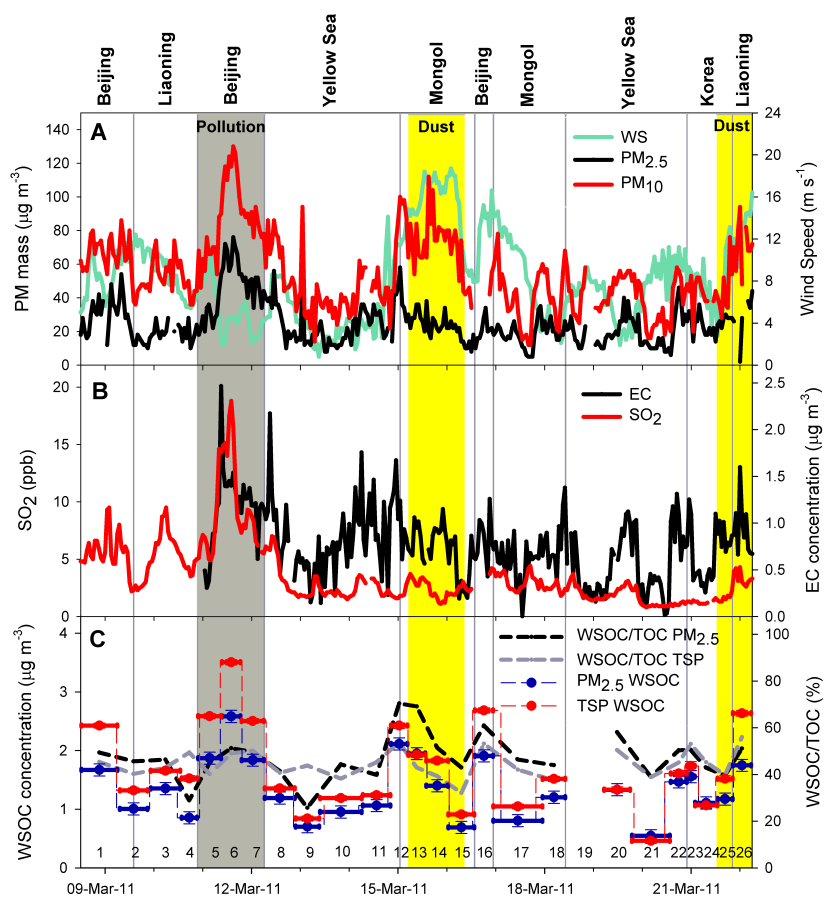

Fig. 2. Pollutant tracers and water-soluble organic carbon concentrations during the March 2011 GoPoEx campaign at KCOG: ambient air particulate mass $\left(\mathrm{PM}_{2.5}\right.$ and $\left.\mathrm{PM}_{10}\right)$ and wind speed (A); concentrations of $\mathrm{SO}_{2}$ provided by South Korean National Institute of Environmental Research (NIER) and semi-continuously measured elemental carbon (EC) (B); concentrations of water-soluble organic carbon (WSOC) and WSOC to total organic carbon (TOC) ratio (C) in both ambient total suspended particles (TSP) and $\mathrm{PM}_{2.5}$ fractions at KCOG during the GoPoEx campaign. The relation between pollutant tracers and back trajectory source regions are marked at the top. The pollution event is marked in grey and the dust events in yellow.

average relative standard deviation of triplicate analysis was $7 \%$ for TSP and $11 \%$ for $\mathrm{PM}_{2.5}$. WSOC was extracted by ultrasonication and quantified by a high-temperature catalytic instrument (Shimadzu-TOC- $\mathrm{V}_{\mathrm{CPH}}$, Japan) as described previously (Kirillova et al., 2010). All WSOC results were blank corrected by subtracting an average field blank value. The WSOC field blanks corresponded to an average $6 \%\left(0.30 \pm 0.06 \mathrm{SD}, \mu \mathrm{g} \mathrm{cm}^{-2} ; n=3\right)$ for TSP and $7 \%$ $\left(0.20 \pm 0.01 \mathrm{SD}, \mu \mathrm{g} \mathrm{cm}^{-2} ; n=3\right)$ for $\mathrm{PM}_{2.5}$ of the field sample loading. Triplicate analysis was done on three TSP and four $\mathrm{PM}_{2.5}$ filters by extracting three different sections of the same filter in order to estimate both analytical and sub-filter variance. The average relative standard deviation of these triplicate analyses was $4 \%$ for TSP and $6 \%$ for $\mathrm{PM}_{2.5}$.

\subsection{Carbon isotope analysis}

Ten samples were chosen for carbon isotope analysis based on an air mass origin from China and sufficient carbon loadings as described in Supplement.

\subsubsection{TOC}

The carbon aerosol TOT analyzer was slightly modified for online isolation of $\mathrm{CO}_{2}$ produced during the combustion of a sample for further measurements of ${ }^{13} \mathrm{C}$ and ${ }^{14} \mathrm{C}$. First, a filter area containing at least $100 \mu \mathrm{g}$ TOC according to the concentration measurements for each sample was acidified by fumigation (as described in Sect. 2.2). The total carbon method was used on the TOT instrument to isolate the entire TOC for subsequent radiocarbon analysis. During this method a $1.5 \mathrm{~cm}^{2}$ subsample was heated at the two ramps to $870{ }^{\circ} \mathrm{C}$ in the atmosphere of helium $(98 \%)$ and oxygen $(2 \%)$ during $110 \mathrm{~s}$ and remained to be exposed to the temperature of $870^{\circ} \mathrm{C}$ for $190 \mathrm{~s}$ until all the TOC was oxidized to $\mathrm{CO}_{2}$.

The $\mathrm{CO}_{2}$ produced by the TOT analyzer was purified through magnesium perchlorate and silver wool traps to remove water and halogen-containing gases, correspondingly. Subsequently, it was cryotrapped in liquid $\mathrm{N}_{2}$ and sealed in the glass ampoules. Further, the $\mathrm{CO}_{2}$ was reduced to graphite, and the carbon isotopic composition was measured at the US NSF National Ocean Science Accelerator Mass Spectrometry (NOSAMS) facility (Woods Hole, MA, USA).

This acid fumigation method was compared with an alternative protocol ("in situ micro-acidification"), in which $150 \mu \mathrm{L} 1 \mathrm{M} \mathrm{HCl}$ was added to the filter subsamples packed into silver capsules, with subsequent drying at $60^{\circ} \mathrm{C}$ for $3 \mathrm{~h}$. Then the concentration of TOC and stable carbon isotope composition were measured at the Stable Isotope Laboratory (SIL) of the Department of Geological Sciences at Stockholm University (Stockholm, Sweden). The instrumental method employed sample combustion with a Carlo Erba NC2500 analyzer connected via a split interface to reduce the gas volume to a Finnigan MAT Delta V mass spectrometer. The differences in TOC mass and stable carbon isotope signature between the two acidification techniques were within the uncertainty estimates for TOC.

\subsubsection{WSOC}

For ${ }^{13} \mathrm{C}$ and ${ }^{14} \mathrm{C}$ analysis a filter area corresponding to at least $150 \mu \mathrm{g}$ WSOC based on concentration measurements for each of 10 chosen samples was acidified by fumigation as described above and extracted as described previously (Kirillova et al., 2010). However, the acid fumigation method described above was compared with an alternative protocol using milder in situ micro-acidification: addition of $150 \mu \mathrm{L} 1 \mathrm{M}$ $\mathrm{HCl}$ to the freeze-dried water extracts, followed by drying at $60^{\circ} \mathrm{C}$ for $3 \mathrm{~h}$. When comparing the $\delta^{13} \mathrm{C}$ signature of the samples using the two acidification methods, the samples analyzed using the in situ micro-acidification protocols were uniformly shifted by $-0.9 \pm 0.7 \%$ o $(n=7)$ compared with the original method. Thus, enrichment in $\delta^{13} \mathrm{C}$ is induced by the original method. This correction was applied uniformly to all samples. Since the $\Delta^{14} \mathrm{C}$ metric is reported relatively to a $\delta^{13} \mathrm{C}$ standard (i.e., $-25 \%$ ), these isotope effects do not 
influence the reported $\Delta^{14} \mathrm{C}$ values. Stable carbon isotope $\left(\delta^{13} \mathrm{C}\right.$-WSOC) measurements were performed at the Stable Isotope Laboratory (SIL) of the Department of Geological Sciences at Stockholm University (Stockholm, Sweden). The radiocarbon measurements of the freeze-dried WSOC isolates were performed at the US-NSF NOSAMS facility as described previously (McNichol et al., 1992; Pearson et al., 1998; Kirillova et al., 2010).

\subsection{Uncertainty estimation}

The overall precision of TC and WSOC concentrations and isotopic signatures was estimated based on uncertainties from several different sources, including the precision of concentration estimation (estimates from triplicate analysis), mass contributions from field blanks (estimates from several blanks), as well as precision of isotope characterization (instrument precision) and the isotope signature of the field blanks (Supplement). To properly account for all uncertainties, we employed an error propagation scheme based on a Monte Carlo strategy as described previously (Kirillova et al., 2013).

\subsection{Light absorption by WSOC}

Light extinction of 13 WSOC samples (both TSP and $\mathrm{PM}_{2.5}$ ) was measured using a Hitachi U2010 spectrophotometer, using the wavelength range of $190-1100 \mathrm{~nm}$. No acidification was implemented to the filters or WSOC extracts utilized for spectroscopic measurements. The mass absorption cross section (MAC) was computed according to the Lambert-Beer law:

$\mathrm{MAC}=\frac{-\ln \left|\frac{I}{I_{0}}\right|}{C \cdot L}=\frac{A}{C \cdot L}$,

where $I$ denote light intensity, $C$ is the concentration of WSOC in solution, $L$ is the light path length (i.e., $1 \mathrm{~cm}$, for the currently used quartz cuvettes) and $A$ is the absorbance (assuming that the scattering contribution to extinction is low). For comparison with previous results, the MAC was computed for $365 \mathrm{~nm}$ (Cheng et al., 2011). Equation (1) predicts a linear relation between absorbance and concentration. This prediction was tested by dilution experiments, and was found to agree well within the currently investigated concentration/wavelength range (data not shown).

The wavelength $(\lambda)$ dependence of the WSOC absorption was investigated by fitting the absorption Ångström exponent (AAE) using the following relation:

$$
\frac{A\left(\lambda_{1}\right)}{A\left(\lambda_{2}\right)}=\left(\frac{\lambda_{2}}{\lambda_{1}}\right)^{\mathrm{AAE}} \text {. }
$$

AAE were fitted within the range $330-400 \mathrm{~nm}$. This range is justified by (1) avoidance of interference by nitrate at $\sim 300 \mathrm{~nm}$ (Cheng et al., 2011). (2) Detailed analysis of wave- lengths $<300 \mathrm{~nm}$ are of lower importance for climate implications, due to the high atmospheric absorbance of ozone in this wavelength range. (3) The low signal-to-noise ratio for wavelengths above $400 \mathrm{~nm}$ for the currently investigated samples. The linear fits of $\log (\lambda)$ vs. $\log (\mathrm{A}(\lambda))$ data (where the slope $=\mathrm{AAE}$ ) showed good correlations, with $R^{2}>0.99$ for all investigated samples in the $330-400 \mathrm{~nm}$ range (Supplement Fig. S5).

\section{Results and discussion}

\subsection{Meteorological setting and air mass characterization}

The climate of Jeju Island is driven by the Asian monsoon system. In late winter and spring, the air masses arriving at KCOG are largely influenced by the anthropogenic activities in China and Korea, and by Asian dust storms (e.g., Carmichael et al., 1996; Huebert et al., 2003; Sahu et al., 2009). The major objective of the Gosan Pollution Experiment (GoPoEx), carried out at KCOG on 8-23 March 2011, was to intercept aerosols from the northern China outflow to study their sources and properties.

To examine the geographical source regions of the air masses during GoPoEx, five-day back trajectories (BTs) were generated at three arrival heights $(100,500$ and $850 \mathrm{~m}$ a.g.l.) for every $6 \mathrm{~h}$ using NOAA HYSPLIT software v4 (http://www.arl.noaa.gov/ready/hysplit4.html). Consideration of both path and heights of the BTs allowed us to determine five main source areas: Beijing, Liaoning, Yellow Sea, Mongol (Mongolia and the Nei Mongol province of China) and the Korean peninsula (Fig. 1, Supplement, Fig. S1-3). The air in the Yellow Sea category circulated for extended times at high altitude over the Jeju region before descending to KCOG, whereas air mass transfer over the other source regions occurred at low altitudes.

Three episodes of elevated pollutant loadings were observed during the high-intensity campaign (Fig. 2): (1) a pollution event was observed from 10:00 p.m. LT of 10 March to 06:00 a.m. of 12 March (filter samples 5-7) with air masses originating from the Beijing area, which was characterized by high loadings of $\mathrm{PM}_{2.5}, \mathrm{PM}_{10}, \mathrm{EC}$ and $\mathrm{SO}_{2}$. (2) An Asian dust episode was observed from 05:00 a.m. of 15 March to 09:00 a.m. of 16 March (filter samples 13-15), originating from the Mongol source sector, which was characterized by high $\mathrm{PM}_{10}$ low $\mathrm{PM}_{2.5}$ and pollution tracers and high wind speeds $\left(13-16 \mathrm{~m} \mathrm{~s}^{-1}\right)$. (3) A second dust event combined with rain was observed from 01:00 p.m. of 21 March to the end of campaign (filter samples 25 and 26).

\subsection{WSOC abundance and distribution}

During GoPoEx, WSOC contributed $\sim 45-47 \%$ of TOC (Fig. 2c). When comparing total suspended particles (TSP) with $\mathrm{PM}_{2.5}$ size fraction, about $80 \%$ of WSOC was found in 
the fine $(<2.5 \mu \mathrm{m})$ fraction. The highest concentrations were found during the pollution event (10-12 March, $2.3 \mu \mathrm{g} \mathrm{m}^{-3}$ in $\mathrm{PM}_{2.5}$ and $3.5 \mu \mathrm{g} \mathrm{m}^{-3}$ in TSP, Fig. 2), but elevated WSOC concentrations were also observed during the two dust events (15-16 and 21-22 March). The concentrations of WSOC during the GoPoEx period are within the range of what has been observed in China (0.4-9.6 $\mu \mathrm{g} \mathrm{m}^{-3}$ for $\mathrm{PM}_{2.5}$ ) (Feng et al., 2006; Pathak et al., 2011; Huang et al., 2012; Cheng et al., 2011).

\subsection{Light absorption of water-soluble organic carbon (WSOC) in outflow from northern China}

Black carbon (BC) is frequently referred to as the major light absorbing aerosol species (e.g., Ramanathan and Carmichael, 2008; Bond et al., 2013). However, other carbonaceous aerosols may also absorb light, but typically with a more pronounced wavelength dependence - "brown carbon" (Andreae and Gelencsér, 2006). For the GoPoEx, the light absorption of WSOC was found to have a wavelength dependence reflected in an absorption Ångström exponent (AAE) ranging between 5.6 and 7.7 (6.4 \pm 0.6 , Supplement Fig. S4). In comparison, the AAE for BC is typically 1 (Hecobian et al., 2010; Cheng et al., 2011; Kirchstetter and Thatcher, 2012). The WSOC AAE for GoPoEx is comparable with observations, using similar extraction protocols, near Beijing, China of 7.2 in summer and 7.5 in winter (Cheng et al., 2011), values of 6.2-8.3 in SE USA (Hecobian et al., 2010), 7.1 over the Amazonas (Hoffer et al., 2006). Similarly, the current range of the receptor-intercepted WSOC mass absorption cross-section values at $365 \mathrm{~nm}\left(\mathrm{MAC}_{365}\right)$ (Fig. 3a) were $0.3-1.1 \mathrm{~m}^{2} \mathrm{~g}^{-1}$ $\left(0.7 \pm 0.2 \mathrm{~m}^{2} \mathrm{~g}^{-1}\right)$, which compares with Beijing source area during winter $(1.8 \pm 0.2$; Cheng et al., 2011), Beijing in summer $\left(0.7 \mathrm{~m}^{2} \mathrm{~g}^{-1}\right.$; Cheng et al., 2011) and with SE USA $\left(0.3-0.7 \mathrm{~m}^{2} \mathrm{~g}^{-1}\right.$; Hecobian et al., 2010). A broad relationship exists between the WSOC light absorption at $365 \mathrm{~nm}$ and WSOC concentration (Fig. S6), with $R^{2}=0.77$ for $\mathrm{PM}_{2.5}$ and 0.83 for TSP. This may be related to different lightabsorbing properties of samples from different source areas and/or different degree of atmospheric processing during long-range transport.

One investigation of light-absorbing properties of WSOC using a particle into liquid sampler (PILS) coupled to an online spectrophotometer shows differences when compared with the water extraction method: AAE fitted between 300 and $600 \mathrm{~nm}$ is $3.2 \pm 1.2$ for PILS measurements and $7.6 \pm 0.5$ for filter extracts (Zhang et al., 2013). In addition, by combing size-resolved solvent extracts with Mie theory, Liu et al. (2013) showed that the absorption of solvent extracts may underestimate the light absorption of WSOC in ambient aerosol by a factor of $\sim 2$. Taken together, these observations emphasize the importance of methods-intercomparisons to reconcile methods-dependent differences. In particular, it is important to note that ambient

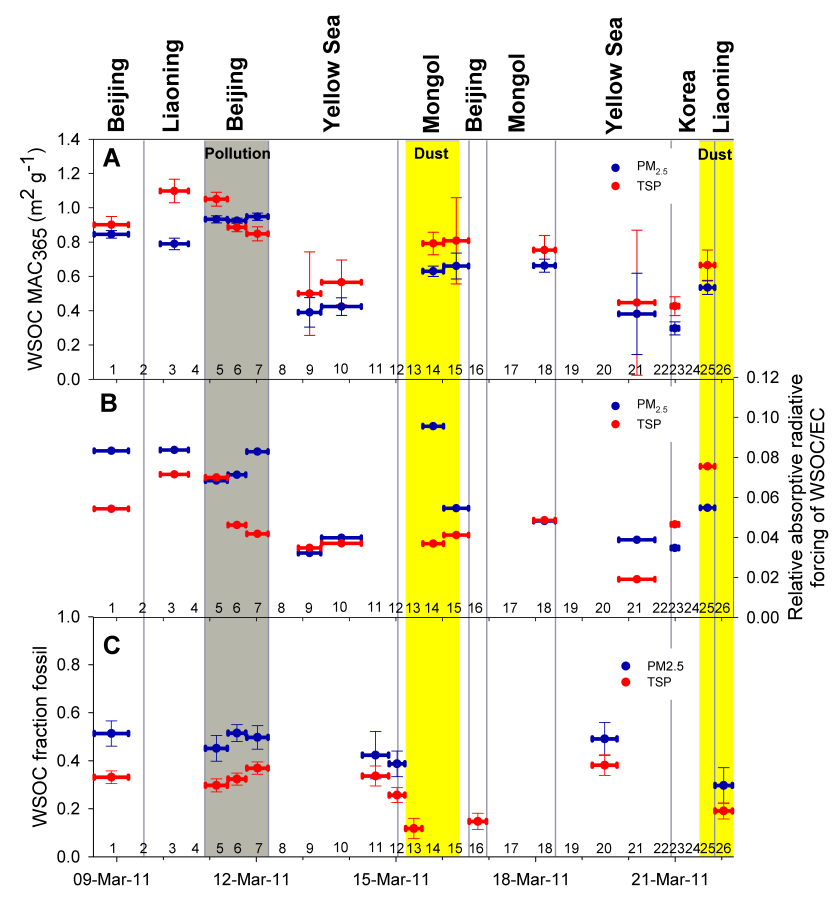

Fig. 3. Mass absorption cross section of water-soluble brown carbon (WSOC) at $365 \mathrm{~nm}\left(\mathrm{MAC}_{365}\right)(\mathbf{A})$; relative absorptive radiative forcing of WSOC compared to that of elemental carbon (EC) (B); radiocarbon-based source-apportionment measurements of fraction fossil in $\mathrm{PM}_{2.5}$ and TSP aerosols at KCOG station during the GoPoEx campaign $(\mathbf{C})$.

carbonaceous aerosols constitute a wide range of compounds with different water solubility. Comparisons of extractions in different solvents, such as water and methanol, indicate that light-absorbing species ("brown carbon") tends to be more soluble in less hydrophilic solvents (Chen and Bond, 2010; Zhang et al., 2013; Liu et al., 2013). In a recent theoretical study, Psichoudaki and Pandis (2013) presented the $p$ parameter (i.e., volume extraction solvent/volume air sampled) as a measure for optimal solvent extraction. The $p$ values for the present WSOC extracts range $0.09-1.22 \mathrm{~cm}^{3} \mathrm{~m}^{-1}$, and fall well within what is described as the "optimal range" of this parameter.

Higher $\mathrm{MAC}_{365}$ values were observed for samples of Chinese origins (Beijing and Liaoning), including the Beijing area pollution plume, than for Mongol and Korea source regions and dust events (Fig. 3a). Samples attributed to the Yellow Sea group are characterized by lower absorbance (MAC) although initially they were influenced by the emissions from Beijing and Liaoning. The relatively lower $\mathrm{MAC}_{365}$ for these samples may reflect source-dependent differences, secondary contributions or other effects of atmospheric processing (e.g., bleaching induced by photochemical aging).

To estimate the relative range of direct climate warming effects due to light absorption of WSOC compared to EC, a simplistic calculation of absorption-based radiative 
forcing was employed (Supplement for details). The relative absorption-based radiative forcing was calculated as the wavelength-dependent integrated product of solar emission and WSOC light absorption attenuation divided by the analogous integral for EC (Supplement Fig. S9). The amount of solar energy absorbed by WSOC relative to EC was 2-10\% during the GoPoEx (Fig. 3b). It should be emphasized that this estimate is a first order approximation; including several simplifying assumptions (see Supplement for further discussion). For instance, the light-absorption by solvent extracts may not reflect the absorption of ambient aerosols, considering the size distribution of the aerosol, the water contents and the effects of internal mixing and their effects on absorption/scattering. However, given its limitations, this estimate indicates that the direct absorption climate effect by WSOC contributes with only a minor climate warming effect. Still this effect offsets some of the expected net cooling due to the indirect effect expected from WSOC, in particular when including additional climate effects such as indirect cloud burn-off effects (Jacobson, 2012).

\subsection{Sources and atmospheric processing of WSOC}

Radiocarbon $\left(\Delta^{14} \mathrm{C}\right)$ has recently been shown to be a powerful technique for differentiating biomass/biofuel burning and biogenic emissions vs fossil sources for different components of Asian carbonaceous aerosols (e.g., Gustafsson et al., 2009; Sheesley et al., 2012; Kirillova et al., 2013). For GoPoEx, radiocarbon measurements of WSOC show that the fossil contribution is as large as the biomass/biogenic contribution in the $\mathrm{PM}_{2.5}$ fraction (Fig. 3c). These values are much higher than what has previously been reported for WSOC in Europe and USA, showing the much larger influence of fossil sources to this large component of aerosol carbon in the northern China outflow. For TSP, the fossil contribution was somewhat lower, showing a large influence from biomass/biogenic coarse mode water-soluble particles. Little variation in time was found during the present campaign, except for the dust episodes, when the biomass/biogenic contribution was larger.

By combining the $\Delta{ }^{14} \mathrm{C}$ with the stable carbon isotope $\left(\delta^{13} \mathrm{C}\right)$ composition, it is possible to examine the dual effects of source variability and atmospheric processing of WSOC as well as of TOC (Kirillova et al., 2013). Since the $\Delta^{14} \mathrm{C}$ parameter is reported relative to a stable carbon standard, this parameter is only sensitive to emission source (biomass burning/biogenic vs fossil) variability. In contrast, $\delta^{13} \mathrm{C}$ is sensitive to both variability of different emissions sources (e.g., coal, petroleum, wood combustion and marine sources) and to atmospheric processing due to the kinetic isotope effect. By considering the two-dimensional $\Delta^{14} \mathrm{C}-\delta^{13} \mathrm{C}$ signal for the GoPoEx campaign, four clusters appear in the following order (from lower left to top right along the E. Asia continuum in Fig. 4): TOC $\mathrm{PM}_{2.5}$, TOC TSP, WSOC $\mathrm{PM}_{2.5}$ and WSOC TSP. The four populations are distributed along a straight line, which is similar to our previous findings for the South Asian outflow (Fig. 4: S. Asia continuum line, Kirillova et al., 2013). Comparison of the East Asian and South Asian data sets show three consistent trends: (1) higher fossil contribution in both WSOC and TOC in E. Asia than in S. Asia; (2) WSOC is more modern (i.e., "younger" ${ }^{14} \mathrm{C}$ signal) and more enriched in ${ }^{13} \mathrm{C}$ compared to TOC in both size fractions for both E. and S. Asia; (3) Coarse particles are more modern and enriched in ${ }^{13} \mathrm{C}$ compared to $\mathrm{PM}_{2.5}$ for both WSOC and TOC.

The enrichment in ${ }^{13} \mathrm{C}$ of WSOC relative to TOC in both East and South Asia may reflect either difference in sources or in atmospheric processing. Particulate emission sources cover a wide range of $\delta^{13} \mathrm{C}$ values: on average $-13 \%$ o for $\mathrm{C} 4$ plants, -22 to $-18 \%$ for marine sources, -23 to $-21 \%$ o for coal, -34 to $-25 \%$ o for C3 plants, -29 to $-24 \%$ o for liquid petroleum and -40 to $-28 \%$ o for gaseous petroleum (e.g., Miyazaki et al., 2007, 2011; Kawashima and Haneishi, 2012; Anghitori et al., 2011; Widory, 2006). For Chinese outflow, $\mathrm{C} 4$ plants (e.g., maize and sugar cane) are not expected to be a large contribution. By combining the isotope data with ratios of inorganic ions isolated from the same filters, marine sources are not expected to have a major influence on WSOC during the GoPoEx (Fig. S10).

The $\delta^{13} \mathrm{C}$ value is also influenced by atmospheric processing (Fig. 4 inset). During formation of secondary organic aerosol (SOA), molecules depleted in heavy isotopes are expected to react faster, leading to depletion in ${ }^{13} \mathrm{C}$. This prediction is supported by laboratory studies (e.g., Iannone et al., 2010; Anderson et al., 2004). In contrast, during atmospheric aging (here meaning reactions with reactive species such as the hydroxyl radical) molecules with lighter isotopes react faster, forming gaseous species such as $\mathrm{CO}, \mathrm{CO}_{2}$ and volatile organic carbon (VOC). This leads to an enrichment of ${ }^{13} \mathrm{C}$ in the residual carbon in the aerosol phase, which has also been supported by laboratory and field studies (Aggarval and Kawamura, 2008; Smith et al., 2009). In addition, aging may also involve rearrangement within the aerosol phase (e.g., condensation reactions), without production of gaseous substances (Kalberer et al., 2004; Zahardis et al., 2006; Nguyen et al., 2011). Since there is then no net transfer of carbon, these reactions do not affect $\delta^{13} \mathrm{C}$ signature of the aerosol TOC, but may change the signature of a subpopulation such as of the WSOC. Semivolatile organic compounds partition between gas and particulate phases causing enrichment of heavier isotopes in the particulate phase. However, laboratory studies indicate these effects are likely to have only a minor effect on the $\delta^{13} \mathrm{C}$ signature (Harrington et al., 1999; Wang and Kawamura, 2006).

Both SOA formation and aging leads to production of more polar compounds, such as WSOC. The higher $\delta^{13} \mathrm{C}$ values $\left({ }^{13} \mathrm{C}\right.$ enrichment) of WSOC compared with TOC either indicates differences in sources or processing. Excluding the less likely candidates $\mathrm{C} 4$ plants and marine contributions, it is unlikely that the observed difference between TOC and 


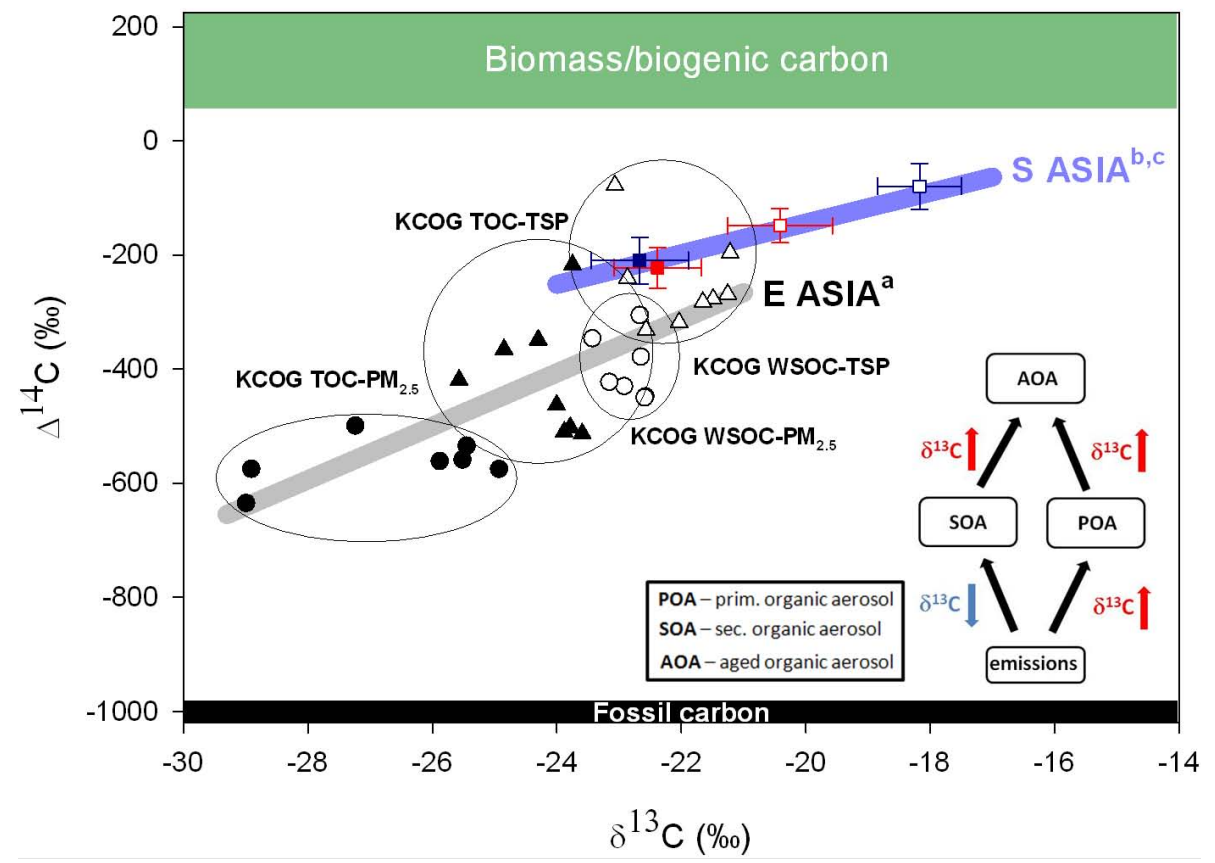

Fig. 4. Two-dimensional presentation of dual-isotope $\left(\delta^{13} \mathrm{C}\right.$ vs. $\left.\Delta^{14} \mathrm{C}\right)$ signals of WSOC and TOC in PM 2.5 and TSP for (A) GoPoEx campaign in East Asia (dust-influenced samples are excluded) compared to in South Asia (B) Sheesley et al. (2012) and (C) Kirillova et al. (2013) data sets from western-central Indian site of Sinhagad (SINH) and Indian Ocean site on Hanimaadhoo Island, Maldives (MCOH). South Asian data are presented as mean values with standard deviation spread for SINH-TOC (red filled squares), MCOH-TOC (blue filled squares), SINH-WSOC (red open squares) and MCOH-WSOC (blue open squares). Linear fits of TOC and WSOC data are presented as a thick light blue line for South Asia and a grey line for East Asia. The bottom right inset graphically summarizes the general trends of the influence of atmospheric processing on the $\delta^{13} \mathrm{C}$ signature of carbonaceous aerosols.

WSOC reflects source differences. Instead, the more probable explanation is that this difference is determined by atmospheric processing/aging since enrichment in ${ }^{13} \mathrm{C}$ is observed (Kirillova et al., 2013). This hypothesis is consistent with the fact that the same TOC vs WSOC trend is observed at all three sites (KCOG, MCOH and SINH) and for two size fractions ( $\mathrm{PM}_{2.5}$ and TSP) (Fig. 4), as well as WSOC being more polar than TOC in general. The more enriched ${ }^{13} \mathrm{C}$ values observed at $\mathrm{MCOH}$ (S. Asia receptor), compared with SINH and KCOG, are likely to reflect a longer sourcereceptor transport time.

The enrichment in ${ }^{13} \mathrm{C}$ observed in WSOC relative to TOC is for the currently examined data sets always correlated with higher biomass $\left({ }^{14} \mathrm{C}\right.$ value) contents. Fossil fuel combustion in general occurs at higher temperatures/pressures than biomass burning. This means that fossil sources of carbonaceous aerosols are more recalcitrant to further chemical oxidation than products of biomass burning and biogenic origins (Elmquist et al., 2006). This observation thus offers an explanation why "aging" (here in the meaning of reactive transformations) of carbonaceous aerosols is preferential for more ${ }^{14} \mathrm{C}$-modern (i.e., biomass) components. In addition, atmospheric processing also offers an explanation why $\mathrm{PM}_{2.5}$ particles are more depleted in ${ }^{13} \mathrm{C}$ than TSP: SOA formation produces particles that rarely grow larger than $2.5 \mu \mathrm{m}$ (Se- infeld and Pandis, 1998). The lower $\delta^{13} \mathrm{C}$ of $\mathrm{PM}_{2.5}$ for both TOC and WSOC are thus expected to reflect larger relative contributions from SOA to the WSOC in $\mathrm{PM}_{2.5}$ than in the TSP pool.

\section{Conclusions}

Radiocarbon $\left({ }^{14} \mathrm{C}\right)$ constraints of carbonaceous aerosols in Chinese outflow show that up to half of water soluble organic carbon (WSOC) (26-49\% in $\mathrm{PM}_{2.5}$ and $12-38 \%$ in TSP) is of fossil origins. This contribution is significantly larger than what has been observed in South Asia, Europe and USA. The direct light absorptive properties of WSOC were found to range $2-10 \%$ relative to that of the main light absorptive aerosol component, elemental carbon. Thus, even though WSOC typically absorb sunlight to some extent, the net climate effect of WSOC during GoPoEx campaign is expected to be cooling. Stable carbon isotope analysis show that the WSOC from the Chinese outflow observed at the Yellow Sea receptor site is subject to aging during long-range transport. 


\section{Supplementary material related to this article is available online at http://www.atmos-chem-phys.net/14/ 1413/2014/acp-14-1413-2014-supplement.pdf.}

Acknowledgements. We are grateful to the PI team of the Korea Climate Observatory at Gosan (KCOG) for maintaining a wellequipped station and for graciously granting access during the GoPoEx. The authors acknowledge financial support from the Swedish Research Council for Environment, Agricultural Sciences and Spatial Planning (FORMAS contract no. 214-2009-970) STINT Foundation (no. 2010/072) and the Korean Center for Atmospheric and Earthquake Research. ÖG also acknowledges financial support as an Academy Researcher from the Swedish Royal Academy of Sciences through a grant from the Knut and Alice Wallenberg Foundation. A. Andersson acknowledges financial support from the Knut and Alice Wallenberg Foundation. This study also benefitted from the research environments provided by the Bolin Centre for Climate Research and the Delta Facility (a core facility for compound-specific isotope analysis), both at the Stockholm University, School of Natural Sciences.

Edited by: Y. Rudich

\section{References}

Aggarwal, S. G. and Kawamura, K.: Molecular distributions and stable carbon isotopic compositions of dicarboxylic acids and related compounds in aerosols from Sapporo, Japan: Implications for photochemical aging during longrange atmospheric transport, J. Geophys. Res., 113, D14301, doi:10.1029/2007JD009365, 2008.

Agnihotri, R., Mandal, T. K., Karapurkar, S. G., Naja, M., Gadi, R., Ahammmed, Y. N., Kumar, A., Saud, T., and Saxena, M.: Stable carbon and nitrogen isotopic composition of bulk aerosols over India and northern Indian Ocean, Atmos. Environ., 45, 2828 2835, 2011.

Anderson, R. S., Iannone, R., Thompson, A. E., Rudolph, J., and Huang, L.: Carbon kinetic isotope effects in the gas-phase reactions of aromatic hydrocarbons with the $\mathrm{OH}$ radical at $296 \pm 4 \mathrm{~K}$, Geophys. Res. Lett., 31, L15108, doi:10.1029/2004GL020089, 2004.

Andreae, M. O. and Gelencsér, A.: Black carbon or brown carbon? The nature of light-absorbing carbonaceous aerosols, Atmos. Chem. Phys., 6, 3131-3148, doi:10.5194/acp-6-3131-2006, 2006.

Asa-Awuku, A., Sullivan, A. P., Hennigan, C. J., Weber, R. J., and Nenes, A.: Investigation of molar volume and surfactant characteristics of water-soluble organic compounds in biomass burning aerosol, Atmos. Chem. Phys., 8, 799-812, doi:10.5194/acp8-799-2008, 2008.

Bahadur, R., Praveen, P. S., Xu, Y., and Ramanathan, V.: Solar absorption by elemental and brown carbon determined from spectral observations, P. Natl. Acad. Sci. USA, 109, 17366-17371, 2012.
Birch, M. E. and Cary, R. A.: Elemental carbon-based method for monitoring occupational exposures to particulate diesel exhaust, Aerosol Sci. Technol., 25, 221-241, 1996.

Bond, T. C., Doherty, S. J., Fahey, D. W., Forster, P. M., Berntsen, T., DeAngelo, B. J., Flanner M. G., Ghan, S., Kärcher, B., Koch, D., Kinne, S., Kondo, Y.,Quinn, P. K., Sarofim, M. C., Schultz, M. G., Schulz, M., Venkataraman, C., Zhang, H., Zhang S., Bellouin, N., Guttikunda, S. K., Hopke, P. K., Jacobson M. Z., Kaiser, J. W., Klimont, Z., Lohmann, U., Schwarz, J. P., Shindell, D., Storelvmo, T., Warren, S. G., and Zender, C. S.: Bounding the role of black carbon in the climate system: A scientific assessment, J. Geophys. Res.-Atmos., 118, 5380-5552, doi:10.1002/jgrd.50171, 2013.

Carmichael, G. R., Zhang, Y., Chen, L.-L., Hong, M.-S., and Uedas, H.: Seasonal variation of aerosol composition at Cheju Island, Korea, Atmos. Environ., 30, 2407-2416, 1996.

Charlson, R. J., Seinfeld, J. H., Nenes, A., Kulmala, M., Laaksonen, A., and Facchini, M. C.: Atmospheric science - Reshaping the theory of cloud formation, Science, 292, 2025-2026, 2001.

Chen, B., Andersson, A., Lee M., Kirillova, E., Xiao, Q., Kruså, M., Shi, M., Hu, K., Lu, Z., Street, D. G., Du, K., and Gustafsson, Ö.: Source forensics of black carbon aerosols from China, Environ. Sci. Technol., 47, 9102-9108, 2013.

Chen, Y. and Bond, T. C.: Light absorption by organic carbon from wood combustion, Atmos. Chem. Phys., 10, 1773-1787, doi:10.5194/acp-10-1773-2010, 2010.

Cheng, Y., He, K.-B., Zheng, M., Duan, F.-K., Du, Z.-Y., Ma, Y.L., Tan, J.-H., Yang, F.-M., Liu, J.-M., Zhang, X.-L., Weber, R. J., Bergin, M. H., and Russell, A. G.: Mass absorption efficiency of elemental carbon and water-soluble organic carbon in Beijing, China, Atmos. Chem. Phys., 11, 11497-11510, doi:10.5194/acp11-11497-2011, 2011.

Chung, C. E., Ramanathan, V., and Decremer, D.: Observationally constrained estimates of carbonaceous aerosol radiative forcing, P. Natl. Acad. Sci. USA, 109, 11624-11629, 2012.

Das, O., Wang, Y., and Hsieh, Y.-P.: Chemical and carbon isotopic characteristics of ash and smoke derived from burning of C-3 and C-4 grasses, Org. Geochem., 41, 263-269, 2010.

de Gouw, J. A., Brock, C. A., Atlas, E. L., Bates, T. S., Fehsenfeld, F. C., Goldan, P. D., Holloway, J. S., Kuster, W. C., Lerner, B. M., Matthew, B. M., Middlebrook, A. M., Onasch, T. B., Peltier, R. E., Quinn, P. K., Senff, C. J., Stohl, A., Sullivan, A. P., Trainer, M., Warneke, C., Weber, R. J., and Williams, E. J.: Sources of particulate matter in the northeastern United States in summer: 1. Direct emissions and secondary formation of organic matter in urban plumes, J. Geophys. Res., 113, D08301, doi:10.1029/2007JD009243, 2008.

Decesari, S., Mircea, M., Cavalli, F., Fuzzi, S., Moretti, F., Tagliavini, E., and Facchini, M. C.: Source attribution of water-soluble organic aerosol by nuclear magnetic resonance spectroscopy, Environ. Sci. Technol., 41, 2479-2484, 2007.

Duvall, R. M., Majestic, B. J., Shafer, M. M., Chuang, P. Y., Simoneit, B. R. T., and Schauer, J. J.: The water-soluble fraction of carbon, sulfur, and crustal elements in Asian aerosols and Asian soils, Atmos. Environ., 42, 5872-5884, 2008.

Elmquist, M., Cornelissen, G., Kukulska, Z., and Gustafsson, Ö.: Distinct oxidative stabilities of char versus soot black carbon: Implications for quantification and environmental 
recalcitrance, Global Biogeochem. Cy., 20, GB2009, doi:10.1029/2005GB002629, 2006.

Feng, J., Hu, M., Chan, C. K., Lau, P. S., Fang, M., He, L., and Tang, X.: A comparative study of the organic matter in $\mathrm{PM}_{2.5}$ from three Chinese megacities in three different climatic zones, Atmos. Environ., 40, 3983-3994, 2006.

Feng, J., Guo, Z., Chan, C. K., and Fang, M.: Properties of organicmatter in $\mathrm{PM}_{2.5}$ at Changdao Island, China - A rural site in the transport path of the Asian continental outflow, Atmos. Environ., 41, 1924-1935, 2007.

Gustafsson, O., Krusa, M., Zencak, Z., Sheesley, R. J., Granat, L., Engstrom, E., Praveen, P. S., Rao, P. S. P., Leck, C., and Rodhe, H.: Brown clouds over South Asia: biomass or fossil fuel combustion?, Science, 323, 495-498, 2009.

Harrington, R. R., Poulson, S. R., Drever, J. I., Colberg, P. J. S, and Kelly, E. F.: Carbon isotope systematics of monoaromatic hydrocarbons: Vaporization and adsorption experiments, Org. Geochem., 30, 765-775, 1999.

Hecobian, A., Zhang, X., Zheng, M., Frank, N., Edgerton, E. S., and Weber, R. J.: Water-Soluble Organic Aerosol material and the light-absorption characteristics of aqueous extracts measured over the Southeastern United States, Atmos. Chem. Phys., 10, 5965-5977, doi:10.5194/acp-10-5965-2010, 2010.

Hoffer, A., Gelencsér, A., Guyon, P., Kiss, G., Schmid, O., Frank, G. P., Artaxo, P., and Andreae, M. O.: Optical properties of humic-like substances (HULIS) in biomass-burning aerosols, Atmos. Chem. Phys., 6, 3563-3570, doi:10.5194/acp-6-3563-2006, 2006.

Huang, H., Ho, K. F., Lee, S. C., Tsang, P. K., Ho, S. S. H, Zou, C. W., Zou, S. C., Cao, J. J., and Xu, H. M.: Characteristics of carbonaceous aerosol in $\mathrm{PM}_{2.5}$ : Pearl Delta River Region, China, Atmos. Res., 104-105, 227-236, 2012.

Huebert, B. J., Bates, T., Russell, P. B., Shi, G., Kim, Y. J., Kawamura, K., Carmichael, G., and Nakajima, T.: An overview of ACE-Asia: Strategies for quantifying the relationships between Asian aerosols and their climatic impacts, J. Geophys. Res., 108, 8633, doi:10.1029/2003JD003550, 2003.

Iannone, R., Koppmann, R., and Rudolph, J.: Stable carbon kinetic isotope effects for the production of methacrolein and methyl vinyl ketone from the gas-phase reactions of isoprene with ozone and hydroxyl radicals, Atmos. Environ., 44, 4135-4141, 2010.

Jacobson, M. Z.: Investigating cloud absorption effects: Global absorption properties of black carbon, tar balls, and soil dust in clouds and aerosols, J. Geophys. Res., 117, D06205, doi:10.1029/2011JD017218, 2012.

Kalberer, M., Paulsen, D., Sax, M., Steinbacher, M., Dommen, J., Prevot, A. S. H., Fisseha, R., Weingartner, E., Frankevich, V., Zenobi, R., and Baltensperger, U.: Identification of polymers as major components of atmospheric organic aerosols, Science, 303, 1659-1662, 2004.

Kawashima, H. and Haneishi, Y.: Effects of combustion emissions from the Eurasian continent in winter on seasonal delta C-13 of elemental carbon in aerosols in Japan, Atmos. Environ., 46, 568579, 2012.

Kirchstetter, T. W. and Thatcher, T. L.: Contribution of organic carbon to wood smoke particulate matter absorption of solar radiation, Atmos. Chem. Phys., 12, 6067-6072, doi:10.5194/acp-126067-2012, 2012.
Kirillova, E. N., Sheesley, R. J., Andersson, A., and Gustafsson, Ö.: Natural abundance ${ }^{13} \mathrm{C}$ and ${ }^{14} \mathrm{C}$ analysis of water soluble organic carbon (WSOC) in atmospheric aerosols, Anal. Chem., 82, 7973-7978, 2010.

Kirillova, E. N., Andersson, A., Sheesley, R. J., Krusa, M., Praveen, P. S., Budhavant, K., Safai P. D., Rao, P. S. P., and Gustafsson, Ö.: ${ }^{13} \mathrm{C}$ - and ${ }^{14} \mathrm{C}$-based study of sources and atmospheric processing of water-soluble organic carbon (WSOC) in South Asian aerosols, J. Geophys. Res.-Atmos., 118, 614-626, doi:10.1002/jgrd.50130, 2013.

Liu, J., Bergin, M., Guo, H., King, L., Kotra, N., Edgerton, E., and Weber, R. J.: Size-resolved measurements of brown carbon in water and methanol extracts and estimates of their contribution to ambient fine-particle light absorption, Atmos. Chem. Phys., 13, 12389-12404, doi:10.5194/acp-13-12389-2013, 2013.

McNichol, A. P., Gagnon, A. R., Jones, G. A., and Osborne, E. A.: Illumination of a black box: analysis of gas composition during graphite target preparation, Radiocarbon, 34, 321-329, 1992.

Miyazaki, Y., Kondo, Y., Han, S., Koike, M., Kodama, D., Komazaki, Y., Tanimoto, H., and Matsueda, H.: Chemical characteristics of water-soluble organic carbon in the Asian outflow, J. Geophys. Res., 112, D22S30, doi:10.1029/2007JD009116, 2007.

Miyazaki, Y., Kawamura, K., Jung, J., Furutani, H., and Uematsu, M.: Latitudinal distributions of organic nitrogen and organic carbon in marine aerosols over the western North Pacific, Atmos. Chem. Phys., 11, 3037-3049, doi:10.5194/acp-11-3037-2011, 2011.

Nguyen, T. B., Roach, P. J., Laskin, J., Laskin, A., and Nizkorodov, S. A.: Effect of humidity on the composition of isoprene photooxidation secondary organic aerosol, Atmos. Chem. Phys., 11, 6931-6944, doi:10.5194/acp-11-6931-2011, 2011.

Pathak, R. K., Wang, T., Ho, K. F., and Lee, S. C.: Characteristics of summertime $\mathrm{PM}_{2.5}$ organic and elemental carbon in four major Chinese cities: Implications of high acidity for water-soluble organic carbon (WSOC), Atmos. Environ., 45, 318-325, 2011.

Pearson, A., McNichol, A. P., Schneider, R. J., Von Reden, K. F., and Zheng, Y.: Microscale AMS (super 14) C measurement at NOSAMS, Radiocarbon, 40, 61-75, 1998.

Psichoudaki, M. and Pandis, S.: Atmospheric Aerosol WaterSoluble Organic Carbon Measurement: A Theoretical Analysis, Environ. Sci. Technol., 47, 9791-9798, 2013.

Ramana, M. V., Ramanathan, V., Feng, Y., Yoon, S.-C., Kim, S.-W., Carmichael G. R., and Schauer, J. J.: Warming influenced by the ratio of black carbon to sulphate and the black-carbon source, Nat. Geosci., 3, 542-545, 2010.

Ramanathan, V. and Carmichael, G.: Global and regional climate changes due to black carbon, Nat. Geosci., 1, 221-227, 2008.

Sahu, L. K., Kondo, Y., Miyazaki, Y., Kuwata, M., Koike, M., Takegawa, N., Tanimoto, H., Matsueda, H., Yoon, S. C., and Kim, Y. J.: Anthropogenic aerosols observed in Asian continental outflow at Jeju Island, Korea, in spring 2005, J. Geophys. Res., 114, D03301, doi:10.1029/2008JD010306, 2009.

Seinfeld, J. H. and Pandis, S. N.: Atmospheric Chemistry and Physics (Wiley, Hoboken, NJ), 1326 pp., 1998.

Sheesley, R. J., Kirillova, E., Andersson, A., Kruså, M., Praveen, P. S., Budhavant, K., Safai, P. D., Rao, P. S. P., and Gustafsson, Ö.: Year-round radiocarbon-based source apportionment 1 of carbonaceous aerosols at two background sites in South Asia, J. Geophys. Res., 117, D10202, doi:10.1029/2011JD017161, 2012. 
Smith, J. D., Kroll, J. H., Cappa, C. D., Che, D. L., Liu, C. L., Ahmed, M., Leone, S. R., Worsnop, D. R., and Wilson, K. R.: The heterogeneous reaction of hydroxyl radicals with submicron squalane particles: a model system for understanding the oxidative aging of ambient aerosols, Atmos. Chem. Phys., 9, 3209-3222, doi:10.5194/acp-9-3209-2009, 2009.

Svenningsson, B., Rissler, J., Swietlicki, E., Mircea, M., Bilde, M., Facchini, M. C., Decesari, S., Fuzzi, S., Zhou, J., Mønster, J., and Rosenørn, T.: Hygroscopic growth and critical supersaturations for mixed aerosol particles of inorganic and organic compounds of atmospheric relevance, Atmos. Chem. Phys., 6, 1937-1952, doi:10.5194/acp-6-1937-2006, 2006.

Szidat, S., Jenk, T. M., Gaggeler, H. W., Synal, H. A., Fisseha, R., Baltensperger, U., Kalberer, M., Samburova, V., Wacker, L., Saurer, M., Schwikowski, M., and Hajdas, I.: Source apportionment of aerosols by C-14 measurements in different carbonaceous particle fractions, Radiocarbon, 46, 475-484, 2004.

Wang, H. and Kawamura, K.: Stable carbon isotopic composition of low-molecular-weight dicarboxylic acids and ketoacids in remote marine aerosols, J. Geophys. Res., 111, D07304, doi:10.1029/2005JD006466, 2006.

Weber, R. J., Sullivan, A. P., Peltier, R. E., Russell, A., Yan, B., Zheng, M., de Gouw, J., Warneke, C., Brock, C., Holloway, J. S., Atlas, E. L., and Edgerton, E.: A study of secondary organic aerosol formation in the anthropogenicinfluenced southeastern United States, J. Geophys. Res., 112, D13302, doi:10.1029/2007JD008408, 2007.

Widory, D.: Combustibles, fuels and their combustion products: A view through carbon isotopes, Combust. Theor. Model., 10, 831$841,2006$.

Wozniak, A. S., Bauer, J. E., Sleighter, R. L., Dickhut, R. M., and Hatcher, P. G.: Technical Note: Molecular characterization of aerosol-derived water soluble organic carbon using ultrahigh resolution electrospray ionization Fourier transform ion cyclotron resonance mass spectrometry, Atmos. Chem. Phys., 8, 5099-5111, doi:10.5194/acp-8-5099-2008, 2008.
Wozniak, A. S., Bauer, J. E., and Dickhut, R. M.: Characteristics of water-soluble organic carbon associated with aerosol particles in the eastern United States, Atmos. Environ., 46, 181-188, 2012a.

Wozniak, A. S., Bauer, J. E., Dickhut, R. M., Xu, L., and McNichol, A. P.: Isotopic characterization of aerosol organic carbon components over the eastern United States, J. Geophys. Res., 117, D13303, doi:10.1029/2011JD017153, 2012b.

Zahardis, J., LaFranchi, B. W., and Petrucci, G. A.: Direct observation of polymerization in the oleic acid-ozone heterogeneous reaction system by photoelectron resonance capture ionization aerosol mass spectrometry, Atmos. Environ., 40, 1661-1670, 2006.

Zhang, Q., Streets, D. G., Carmichael, G. R., He, K. B., Huo, H., Kannari, A., Klimont, Z., Park, I. S., Reddy, S., Fu, J. S., Chen, D., Duan, L., Lei, Y., Wang, L. T., and Yao, Z. L.: Asian emissions in 2006 for the NASA INTEX-B mission, Atmos. Chem. Phys., 9, 5131-5153, doi:10.5194/acp-9-5131-2009, 2009.

Zhang, X., Lin, Y.-H., Surratt, J. D., Zotter, P., Prévôt, A. S. H., and Weber, R. J.: Light-absorbing soluble organic aerosol in Los Angeles and Atlanta: A contrast in secondary organic aerosol, Geophys. Res. Lett., 38, L21810, doi:10.1029/2011GL049385, 2011.

Zhang, X., Lin, Y. H., Surratt, J. D., and Weber, R. J.: Sources, composition and absorption Ångström exponent of light-absorbing organic components in aerosol extracts from the Los Angeles basin, Environ. Sci. Technol., 47, 3685-3693, 2013. 